\title{
MEASURING THE SPILLOVER TO DISABILITY INSURANCE DUE TO THE RISE IN THE FULL RETIREMENT AGE
}

\author{
Norma B. Coe and Kelly Haverstick
}

CRR WP 2010-21

Date Submitted: November 2010

Date Released: December 2010

\author{
Center for Retirement Research at Boston College \\ Hovey House \\ 140 Commonwealth Avenue \\ Chestnut Hill, MA 02467 \\ Tel: 617-552-1762 Fax: 617-552-0191 \\ http://crr.bc.edu
}

Norma B. Coe is associate director of research for the Center for Retirement Research at Boston College (CRR). Kelly Haverstick is a research economist at the CRR. The research reported here was performed pursuant to a grant from the U.S. Social Security Administration (SSA) funded as part of the Retirement Research Consortium (RRC). The opinions and conclusion expressed are solely those of the authors and do not represent the opinions or policy of SSA, any agency of the federal government, the RRC, or Boston College.

(C) 2010, by Norma B. Coe and Kelly Haverstick. All rights reserved. Short sections of text, not to exceed two paragraphs, may be quoted without explicit permission provided that full credit, including (C) notice, is given to the source. 


\title{
About the Center for Retirement Research
}

The Center for Retirement Research at Boston College, part of a consortium that includes parallel centers at the University of Michigan and the National Bureau of Economic Research, was established in 1998 through a grant from the Social Security Administration. The Center's mission is to produce first-class research and forge a strong link between the academic community and decision makers in the public and private sectors around an issue of critical importance to the nation's future. To achieve this mission, the Center sponsors a wide variety of research projects, transmits new findings to a broad audience, trains new scholars, and broadens access to valuable data sources.

\section{Center for Retirement Research at Boston College}

\author{
Hovey House \\ 140 Commonwealth Avenue \\ Chestnut Hill, MA 02467 \\ phone: 617-552-1762 fax: 617-552-0191 \\ e-mail: crr@bc.edu \\ crr.bc.edu
}

Affiliated Institutions:

The Brookings Institution

Massachusetts Institute of Technology

Syracuse University

Urban Institute 


\begin{abstract}
The increase in the full retirement age in the Social Security program provides exogenous variation in the generosity in the Social Security Disability Insurance (SSDI) program, based only on birth year. We exploit this variation to estimate how responsive SSDI applications are to the financial incentive to apply. We find that a 1-percentage-point decrease in the retirement-to-disability benefit ratio leads to a 0.25 -percentage-point increase in the SSDI application rate for the sample, which represents an 8-percent increase in applications per two years. When weighted to account for sampling design, we estimate that this change in the financial incentive accounted for about 5 percent of the SSDI applications in 2009. However, we do not find a corresponding increase in SSDI receipt based on the financial incentives. In addition, we find little difference in the covariates for individuals who eventually receive SSDI, suggesting that the increase in applications may increase the administrative costs of the SSDI program, but should not have a dramatic impact on the long-term financial solvency of the program.
\end{abstract}




\section{Introduction}

The Social Security Amendments of 1983 increased the full retirement age (FRA) from 65 to 67. The policy affected birth cohorts differently: people born in 1937 or earlier still have an FRA of 65, those born between 1938 and 1959 face a rising FRA by birth year, and those born in 1960 or later face an FRA of 67. These later cohorts also face a greater actuarial reduction in their Social Security benefits if they claim between the Earliest Eligibility Age (EEA) of 62 and their FRA. However, the Amendments did not change the Social Security Disability Insurance (SSDI) program. Therefore the SSDI program has become relatively more attractive for the later birth cohorts because the value of disability benefits has increased relative to Social Security retirement benefits. This relationship is illustrated in Figure 1.

Since 1985, the SSDI rolls have increased dramatically, and the growth in the relative generosity of SSDI compared to Old Age benefits is an often-cited reason (Autor and Duggan, 2006). One component of this increase in generosity is driven by the increase in the FRA. However, the early literature (Mitchell and Phillips, 2000 and Bound et al., 2004) estimated a negligible behavioral response to the increase of the FRA in terms of increased SSDI applications. Their analysis was done before the cohorts impacted had reached age 65, so in essence these studies made out-of-sample predictions. More recent work estimates larger behavioral responses. Duggan et al. (2007) use administrative data and focus on enrollment, not applications. They find that the Social Security Amendments have increased SSDI enrollment, with an additional 0.6 percent of men ( 0.9 percent of women) aged 45-64 receiving benefits in 2005. However, because they use aggregate data, the authors are unable assess how the composition of the SSDI enrollees has changed over time, and have a harder time ruling out other macro-level changes that may be occurring at the same time, such as changes in insurance coverage, changes in the screening criteria of the SSDI program, or differences in the underlying health of the younger cohorts. Li and Maestas (2008) use the Health and Retirement Study (HRS) and find that the increased FRA on the probability of applying for SSDI (0.04-0.30-percentage-point increase in the two-year application rate). However, they do not control for SSDI insurance status or examine how SSDI receipt is impacted by these increased applications. 
This paper measures how responsive individuals are to the new financial incentives to apply for SSDI benefits using micro data. First, we address the potential confounding issue of changes in SSDI insurance coverage by birth cohort. We then measure how responsive people are to the exogenous change in the financial incentives to apply to SSDI. Finally, we consider how disability benefit receipt has changed, to understand if this increase in the application rate means more than just increased administrative costs to the Social Security trust funds. The answer could impact the longevity estimates of the Social Security trust funds.

The paper proceeds as follows. Section 2 describes the data and the SSDI eligibility criteria in detail. Section 3 evaluates who is insured for SSDI, and whether earlier birth cohorts are comparable to older ones, and Section 4 provides a descriptive analysis of the data. Section 5 outlines the econometric methodology while Section 6 presents our results. Conclusions follow in Section 7.

\section{Data}

We use the publicly available HRS from 1992 through 2008, merged with the SSA Detailed Earnings Records (HRS-SSA) (the administrative earnings records are available through 2005). By using the Social Security administrative data, we can: correctly determine SSDI insurance status based on employment history; calculate the Social Security and Disability benefits accurately; and create a measure of lifetime earnings. The SSA's earnings records span from 1950 to the last year the respondent gave permission to link the data, and provides each respondent's annual earnings and a running total of the number of Social Security covered quarters. For those who last gave permission to match to Social Security data before the end of the survey, we supplement the earnings history with self-reported data, averaging two adjacent waves for the intervening years, and cap the earnings at the SS taxable maximum. The number of 
covered quarters is updated based on the annual earnings and the earnings threshold set by SSA. ${ }^{1}$

Table 1 delineates the sample cuts made to the dataset. Almost 32 percent of the total sample is lost because they do not match with administrative records. ${ }^{2}$ We further limit the sample to those born between 1935 and 1943, inclusive. We lose 52 percent of these person-wave observations by only examining behavior between ages 56 and 63 . Only 74 percent of the individuals and 68 percent of these person-wave observations are insured by SSDI, by having worked the required number of quarters based on age, and 20 quarters within the last 10 years. One hundred ninety-five individuals are dropped because they are already applying for or receiving SSDI benefits, and 127 are dropped because they are not observed again in the survey, thus we cannot determine if they apply for SSDI benefits in the next two years. An additional 102 respondents are dropped because of item non-response. Finally, for reasons discussed below, we omit married women from the analysis, leaving 2,838 individuals and 9,050 person-wave observations in the sample.

\section{Who is Insured for SSDI?}

The timing of the 1983 FRA changes allows us to create treatment and control groups: those born 1938-1943 (the treatment group), and those born 1935-1937 (the control group). A simple difference-in-difference approach will be suited to the analysis as long as these birth cohorts are similar on other dimensions. One concern, however, is that labor force participation rates may vary between birth cohorts, leading to differential proportion of workers insured for SSDI benefits. Mitchell and Phillips (2001) document varying age patterns of SSDI insurance coverage based on gender and marital status. Autor and Duggan (2006) mention the increasing labor force participation of women leading to a larger pool of insured workers as a reason for the increasing SSDI enrollment rates. Juhn and Potter (2006) document increasing female labor force participation at ages 25-54 from 1950-2000, and a slight increase from the mid-1980s through the beginning of the 2000s for women aged 55 and older. This pattern arouses concern that

\footnotetext{
${ }^{1}$ While the rules always refer to "covered quarters," since 1978 it is actually calculated by the amount one makes in a calendar year, not the amount of time one was employed. In 2010, earnings of $\$ 1,120$ are required to earn one quarter of coverage.

${ }^{2}$ Previous research (Olson 1999; Haider and Solon 2000; Kapteyn et al. 2006) has shown that failure to match to the SSA data does not introduce bias.
} 
SSDI coverage patterns may vary based on birth year even after controlling for observable characteristics. If later birth cohorts have a much higher percentage of women insured by SSDI or a lower percentage of men insured by SSDI, then there is a potential selection issue that must be addressed if there is any correlation between what impacts the insurance status and what impacts the decision to apply for SSDI.

In order to test this concern, we calculate insured status at age 55 , the age before we start the SSDI-application and enrollment analyses. We first eliminate individuals who die or who are already receiving SSDI benefits by age 55. Being insured for SSDI at 55 is purely a function of previous work history; one must have worked 33 quarters over his or her lifetime and have worked 20 quarters in the last 10 years. ${ }^{3}$ We run the following regression on all individuals born between 1935 and 1943:

$$
I_{i}=\beta_{1} Y_{i}+\beta_{2} \gamma_{i}+\varepsilon_{i}
$$

where I is an indicator variable for whether individual (i) is insured by SSDI at age 55, Y is a vector of control variables, including educational attainment, marital history (ever divorced or ever widowed), and the age one had his last child. Also included in $\mathrm{Y}$ is an indicator variable for whether or not the individual was interviewed "early" in the HRS, which helps account for the survey sample design. ${ }^{4} \gamma_{i}$ is a vector of birth year indicators, with the excluded case being those born between 1935 and 1937. These regressions are run separately for each gender/marital status group because Mitchell and Phillips (2001) find considerable heterogeneity in the determinants of coverage for men, single women and married women. Table 2 presents the results.

First thing to note is that more than 85 percent of married men are insured for SSDI at age 55, while only 60 percent of married women are insured. For men, very few of the demographic controls are correlated with being insured for SSDI. Three variables are significant at the 10-percent level for married men: having a high school degree

\footnotetext{
${ }^{3}$ In order to be insured for SSDI, one must have worked a total of (years old-22) quarters and have worked 20 quarters in the last 10 years.

${ }^{4}$ Individuals born in 1942 and 1943 are considered part of the War Baby cohort by the HRS, and were only added to the survey in 1998. However, a substantial number of individuals, especially women, in these birth years were interviewed prior to 1998 because their husbands were part of the HRS cohort of interest. The weights would normally address this issue; however, because this regression looks at insurance status at a particular age, not a particular year, the weights are inappropriate. This indicator variable allows for those who joined the survey early to be not necessarily representative of the birth year before the full birth year is represented.
} 
(compared to those who didn't finish), not being able to calculate their age when their last child was born, and being born in 1941. Interestingly, if we omit the marital history variables, the 1941 birth year becomes insignificant. Only our inability to determine how old single men were when their last child was born is significant in the regression. Clearly there is not a trend in insurance coverage rates at age 55 by birth year for men.

The demographic controls are highly correlated with SSDI insurance status for women. There are increasing rates of coverage with educational attainment, with a slight drop for those who have at least a college degree. Not surprisingly, delayed or prolonged fertility is negatively related to SSDI coverage because having young children in the house is negatively correlated with labor force participation for women. The indicator that helps correct for the HRS design is strongly significant for single women, suggesting these women were interviewed with their husbands before 1998, and are recently divorced by age 55. For single women, being born in 1939 is marginally significant but, much like married men, there is no indication that there is a trend in SSDI insurance coverage by year of birth. However, for married women, both 1940 and 1942 are significant at the 5-percent level, thus we are reluctant to say that there is little trend in SSDI insurance coverage based on birth year. We tested a variety of other controls, such as number of children, state or local government employee indicators, and duration of marriage, and consistently find significant effects of birth year, indicating an increasing proportion of married women eligible for SSDI benefits for each birth year. This suggests that married women born in 1935-1937 are not a comparable control group for those born in later years because they have consistently weaker attachment to the labor force. Therefore we drop married women from the analysis to avoid biased estimates.

\section{Descriptive Statistics}

Table 3 presents the descriptive statistics for the entire analysis sample, and separated by gender. The averages are based on person-wave observations, and are not weighted.

The dependent variable in our regression analysis indicates whether a respondent applies for SSDI between the date of their interview and the next two full calendar years. For example, if a person is interviewed in June 1998, we examine whether he or she 
applies for SSDI between June 1998 and January 2001. ${ }^{5}$ Only 3 percent of the sample applies during a two-year period. In total, 9 percent of our sample applies during the observation period.

The exogenous generosity measure identifying the impact of SSDI generosity on SSDI applications is the ratio of retirement benefits to SSDI benefits at time $t+1$. This is determined solely by birth year due to the actuarial adjustment made with the increasing FRA. It ranges from 75 percent to 93 percent, and averages around 80 percent for the sample. The average relative generosity of SSDI compared to retirement benefits is virtually identical across the subgroups, which means there are not substantial differences in birth years represented.

Work history and earnings vary considerably by gender, as is evident in the monthly SSDI or full retirement benefit and the total number of covered quarters. Using the disability benefit formula and the earnings histories, we calculate the Primary Insurance Amount (PIA), the monthly benefit amount the respondent would receive were he to become disabled immediately and later receive SSDI. This is solely a function of individual work history, and is a good summary measure of lifetime income. While the average benefit amount is just over $\$ 1,300$, there is quite a bit of variation between men and women: the average benefit of men $(\$ 1,438)$ is almost twice that of (single) women (\$874). ${ }^{6}$ Further, women have worked an average of eight fewer years than the men in the sample.

Health and disability status are expected to be the largest determinants in the SSDI application decision. Activities of daily living (ADL) measure the respondent's inability to do 13 routine daily tasks without difficulty; on average the sample has problems with 1.5 tasks. $^{7}$ Self-reported health is measured on a five-point scale, and 16 percent of the sample reports themselves to be in the lowest two categories of fair or poor

\footnotetext{
${ }^{5}$ If the respondent was uncertain whether he or she had applied for SSDI or Supplemental Security Insurance (SSI), or the RAND files indicate a probable incorrect response, we assume that individuals who are eligible for SSDI applied for SSDI because the financial benefit is significantly higher than SSI and the disability determination criteria is identical.

${ }^{6}$ We do not take into account spousal benefits in these calculations; this is only the benefit based on one's own earnings history. Thus, it reflects individual work history, not household work history.

${ }^{7}$ The daily activities include: bathing, dressing, eating, toileting, getting up from bed, sitting for two hours, climbing one flight of stairs, climbing several flights of stairs, getting up from a chair, stooping and kneeling, walking one block, walking several blocks, and pushing large objects.
} 
health. Twenty to 25 percent, on average, report having frequent pain. RAND calculates a useful benchmark for longevity expectations, namely the ratio between one's selfreported probability of living to age 75 to their statistical probability of living to the same age, using standard life tables. The average self-assessed longevity expectations are 96 percent of the statistical probability, pretty much in line with the life tables. However, single women in this sample estimate their longevity to be significantly less than the life tables (89 percent on average). The average respondent in the sample has 1.24 selfreported major health conditions, which include high blood pressure, diabetes, cancer, lung disease, heart problems, stroke, psychological problems, and arthritis. Only some of these would lead to SSDI acceptance. There are known reporting errors with selfreported height and weight measures (Cawley and Burkhauser 2006). Therefore we use measured height and weight from the 2004 and 2006 waves to correct the self-reported information and measure body mass index (BMI). BMI equal to or greater than 30 is considered obese. The single women in our sample tend to be in worse health than the men. They have more ADLs and other functional limitations, more health conditions, higher percentage of obesity, and assess their mortality to be higher than the life table. Not surprisingly, then, they are more likely to have applied for SSDI in the past, but had been rejected.

Health insurance, and where health insurance coverage is accessed, could be determinants in the decision to apply for SSDI (Autor and Duggan 2006; Gruber and Kubik 2002). While 80 percent of the sample has health insurance, men are 8 percent more likely to have health insurance than the women. We categorize the source of the health insurance, either through their employer, a spouse's employer, or the government, including: Medicaid, Medicare, Veteran’s Administration, CHAMPUS, or other government programs. ${ }^{8}$ While more than 65 percent of all three groups get health insurance through their own employer, an additional 11 percent of men get their health insurance through their spouse, an avenue of coverage virtually unavailable to the single women in the sample.

\footnotetext{
${ }^{8}$ Some respondents continue to receive insurance coverage from a spouse's employer despite a divorce or the death of their spouse. These categories are not exclusive.
} 
The general picture shows that there is little difference in the age and education between men and women. However, there are substantial racial differences; almost 36 percent of the single women sample is a minority, while only 20 percent of the male sample is a minority. ${ }^{9}$

Household non-labor income represents alimony, other income, and lump sum payments from insurance, pension, and inheritance, and does not include income from wages from either spouse. Net worth includes all financial wealth and the primary residence, but excludes Social Security and defined benefit pension wealth. To address a potential “Ashenfelter dip” in wages before applying for SSDI, we prefer to use the threeyear average earnings (in real 2006 dollars) for the last three years worked before appearing in the survey instead of the typical last-year measure. The women are poorer than the men in the sample, in all three of these measures.

Job characteristics may also impact the SSDI application decision, both because of the likelihood to be injured and the ease of completing a job with a disability. Blueand white-collar job determination is based on the occupation code of the current job if the respondent is working, and the last job if they are not. White-collar jobs include managerial, professional, sales, clerical and administrative. Almost 40 percent of the sample has a blue-collar job, with men about 12 percent more likely to have a blue-collar job than women.

\section{Methodology}

We estimate the effect of the SSDI generosity on the two-year SSDI application decision using person-wave data. Instead of relying on differences in individual benefit levels to identify the relationship, we use changes in the Social Security FRA as exogenous variation in program generosity across cohorts.

We estimate the following probit regression:

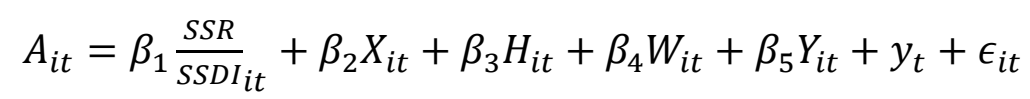

where A is the two-year application decision for individual $i$ between time $t$ and $t+2$. $\frac{S S R}{S S D I}$ is the variable of interest, the ratio of retirement benefits to SSDI benefits, first

\footnotetext{
${ }^{9}$ These rates are higher than in the general population because of the HRS survey design to oversample minority groups, and these descriptive statistics are not weighted to correct for survey design. We do weight the marginal effects to take into account the sample design in section 5.3 when we discuss the impact of the law changes on the total number of SSDI applications.
} 
introduced in Duggan et al. (2007). $X$ is a vector of demographic characteristics, including age dummies and race. $H$ is a vector of health conditions, which we expect to be highly correlated with the SSDI application decision. It also includes indicators for current health insurance coverage and previous SSDI applications and outcomes.

Previous applications have been found to be significant predictors for future applications (Benitez-Silva et al., 1999). W is a vector of wealth components, including household non-labor income, household net worth, and the total number of quarters of work covered by Social Security, to capture attachment to the labor force. $Y$ is the vector of individual characteristics that were used in the regression on insurance status (educational attainment, ever divorced, ever widowed, the age one had his last child, and "early” HRS interview indicator). Finally, the regressions also include year indicator variables, which capture the macroeconomic conditions that are correlated with the decision to apply for SSDI (Autor and Duggan, 2006). Because individuals could be in the sample multiple times, we cluster the standard errors on the person-level.

\section{Results}

\subsection{SSDI Application}

The baseline results for an individual's decision to apply for SSDI are presented in Table 4. In the first column the pooled results are shown, column 2 presents the estimation with only men, and column 3 is for (single) women. Married women are omitted due to the growth in SSDI insurance rates based on birth year that may bias the estimates.

The first thing to note in Table 4 is the very significant and relatively large impact that the relative generosity of SSDI compared to Social Security benefits has on the SSDI application decision. There also seems to be variation in reactivity based on gender, with the size and statistical impact being driven by the men in the sample. We calculate the average of the marginal effect for individuals (Bartus 2005), and find that a 1-percentage-point decrease in the benefit ratio leads to a 0.25 -percentage-point increase in the SSDI application rate for the sample as a whole, with a 0.40-percentage-point increase for men in the sample. Single women do not significantly change their SSDI application behavior. This is consistent with Song and Manchester (2007), who find women are less responsive to other financial incentives built into the Social Security 
system as well. Based on an average two-year application rate of 3.1 percent for the entire sample, this represents an 8-percent increase in applications for this sample (13 percent increase for men). To determine the impact of the change in the financial incentives at the population level, we weight the sample when calculating the marginal effects to take into account the sampling design of the HRS. The marginal effects are not sensitive to the weighting, and remain at 0 for women and 0.40 for men.

In general, bad health is positively related to SSDI applications, as expected. However, the predictive power of the health measures is driven by the men in the sample. Women are less likely and single men are more likely to apply to SSDI overall, while there are no race patterns evident in the application patterns after controlling for all the health, wealth, and employment factors in the SSDI application decision. In the pooled sample, there is suggestive evidence of an age-trend in applications (Duggan et al. 2007), but this disappears once the sample is divided by gender.

Out of the wealth controls, only the total SSA covered quarters, which measures the attachment to the labor force over one's entire lifetime, seems to impact the decision to apply for SSDI benefits, and the effect is driven by men in the sample. Every additional quarter is associated with an increase in the SSDI application rate by 0.03 percentage points for men. Finally, the coefficient on ever being divorced is significant in the application probit for single women, but the marginal effect is not significantly different from zero (Norton et al. 2004).

\subsection{Heterogeneous Effects}

We explored potential avenues for heterogeneous effects of the financial incentives on the SSDI application decision by limiting the sample. However, we find very little evidence for heterogeneous effects beyond that of gender presented in Table 4. We checked for differences based on job characteristics (blue-collar workers, like your job, hiring and firing control in the job), attitude (based on previous work on the relationship between personality and financial outcomes, such as Roberts et al.2007; Judge et al. 1999; Duckworth and Weir 2010), education to proxy for job opportunities, source of health insurance (Autor and Duggan 2006; Gruber and Kubik 2002), and individuals experiencing lower-than-average wage growth (Autor and Duggan 2006). Only the type of occupation had a differential impact. Blue-collar workers in general are 
more likely to apply for SSDI (marginal effect of 0.65), and they are more likely to respond to the financial incentives. For a one-percentage-point change in the ratio of retirement-to-disability benefits, blue-collar workers are 0.39 percentage points more likely to apply, while white-collar workers are only 0.16 percentage points more likely to apply.

\subsection{Specification Checks}

The colinearity of the myriad of the health variables is a serious concern. We conducted a principle component analysis of 20 health variables and included the first principal component as a summary measure of health in the regression analysis, and the results are virtually unchanged. ${ }^{10}$ We keep the individual health variables in the regressions because they are interpretable.

We have also excluded from the sample individuals who have ever applied for SSDI, either with a rejection or receipt, in order to see if this prior interaction with the program impacts the measured results. Benitez-Silva et al. (1999) show that previously applying is a strong predictor for future applications, but previous appliers may differ on other dimensions as well. The results are quantitatively unchanged when the previous applicants are omitted from the sample.

\subsection{Quantifying the Effects: Total Increase in Applications}

So far we have documented that SSDI applications are sensitive to the financial incentives to use SSDI as a labor force exit route. In order to quantify the results, we calculate the number of new applications by birth year in Table 5, based on our estimates. Column 1 shows the percentage point decrease in the retirement-to-disability benefit ratio, by birth year. The average marginal effect for the two-year application decision is 0.40 , which then gives us the percentage-point increase in the number of applications in column 3. From the Current Population Survey, we tally the number of men in each birth cohort in the year they turn 55. We assume an average SSDI insurance rate of 85

\footnotetext{
${ }^{10}$ The health variables used for principal component analysis include: self-reported health, heart attack, stroke, cancer, arthritis, lung disease, heart failure, angina, high blood pressure, diabetes, incontinence, incontinence missing, married, psych problems, cognition, cognition missing, ADL limitations, probability of living to 75, probability of living to 75 missing, and pain frequency.
} 
percent, based on our earlier estimates (Table 2). Multiplying columns 3, 4, and 5 gives us the total number of additional SSDI applications for each birth year in a two-year period. For those born in 1938, they experience a relatively small decrease in benefits -0.8 percentage points -- leading to very few additional applications $(2,993)$. Those born in 1943, however, experience a 5-percentage-point decrease in SS benefits, and thus our estimates suggest an increase of 24,615 applications over two years. If we then assume that this is a constant increase per two-year period, we can then calculate the total number of additional SSDI applications during the 10-year period between ages 55 and 65, by birth year. This simple calculation means an additional 123,000 applications from the 1943 birth year between ages 55-65, and a total of an additional 333,000 applications from these birth years between ages 55-65. If the birth years between 1944 and 1954 respond similarly to those born in 1943 (they all have the same FRA of 66 years) it totals an additional 146,000 applications in the year 2009. To put this number in perspective, the SSA processed 2.8 million applications that year, so about 5 percent were induced by the financial incentives.

\subsection{Effect on SSDI Benefit Receipt}

The impact the extra applications have on the Social Security trust funds depends on the outcome of the applications. If the induced applicant is healthier than average, or more likely to be rejected, then the impact is limited to the increase in administrative costs. However, if the induced applicants have similar or higher acceptance rates, then it could lead to greater benefits paid, decreasing the solvency of the disability trust fund to the benefit of the old age trust fund.

First, we test for differences in the acceptance rate. Limiting the above sample to only those who apply for SSDI ( $\mathrm{n}=245)$, we follow each application over time to see if the application was approved or denied. We test if there are significant differences in the acceptance rate by running a probit regression on the outcome of the application and the ratio of retirement-to-disability benefits at the year of application. We find that those who have lower benefit ratios are significantly less likely to have their application accepted (coefficient $=-5.215$, standard error $($ s.e $)=2.81$ ). Similarly, if we run a probit regression on the outcome of the application and a simple dummy variable indicating "treatment group" (born between 1938-1943), this group is less likely to have their 
application accepted (coefficient $=-0.34$, s.e. $=0.16$ ). This suggests that either the program has become harder to get on, or these induced applicants are not having similar success rates as the applicants born between 1935 and 1937.

To test for increased enrollment, we examine the sample who has reached their FRA (this eliminates those born after 1941 from the sample), were insured for SSDI but not receiving it at age 55. We determine if they have ever received SSDI payment between age 55 and their FRA, and run the following regression:

Receipt $_{i}=\beta_{1}$ BirthYear $_{i}+\beta_{2} X_{i}+\beta_{3} H_{i(\text { age66 })}+\beta_{4} W_{i(\text { age66 })}+\beta_{5} Y_{i(\text { age } 66)}+\epsilon_{i t}$

where Receipt is an indicator for receiving SSDI benefits between ages 55 and 65. Birth year is the vector of birth-year dummy variables. $\mathrm{X}, \mathrm{H}, \mathrm{W}$, and $\mathrm{Y}$ are generally the same vectors of variables as in equation (2). The two exceptions are that we measure health status as of age 66 and we omit expectations on living past age 75 because older respondents are not asked about this. ${ }^{11}$ The results are presented in Table 6. We find no differential impact of birth year on the SSDI receipt between ages 55 and 66. However, the standard errors are relatively large, so we cannot say there have not been small increases in enrollment. Importantly, we cannot reject the earlier findings of Autor and Duggan (2006) that find an increase of 0.6 percent in the number of men receiving SSDI. Our findings do suggest, however, that the increased applications that are induced by the financial incentives are likely not leading to dramatically more SSDI payments.

To further test this hypothesis, we compare the characteristics of those who apply for SSDI based on birth year. The means of each group are presented in Table 7. There does seem to be considerable variation between the applicant pools. First, the individuals in the older group of men are more likely to be veterans, as shown by the source of health insurance. The younger men seem to be sicker at first glance, based on the count of major conditions and higher obesity rate. However, the difference in the average number of major conditions is driven by increased cancer, diabetes, and high blood pressure. The latter two are likely related to an increase in obesity and diagnosis behavior, and not impact one's likelihood of receiving SSDI. The younger men are also more likely to have a college degree and have a stronger historical attachment to the labor force, as

\footnotetext{
${ }^{11}$ We pick age 65-67, depending on when individuals responded to the survey. Forty-four percent were age 66.
} 
measured in total covered quarters and full benefit amount. This is suggestive of the fact that these younger applicants may be more readily trainable for different jobs, and might be less likely to receive SSDI benefits. Finally, when we test for differences in the covariates for those who receive SSDI benefits between ages 55-65, the only significant difference between those born in 1935-1937 and those born 1938-1941 is that the later birth cohort tends to be poorer, as measured by full Social Security benefit amount. There is no difference in health characteristics at age 66.

\section{Conclusion}

The increase in the FRA was a measure to improve the long-term financial outlook of the Social Security trust funds. The effectiveness of this policy change depends not only on how it impacts an individual's work and claiming decisions, but also on his decision to apply for SSDI benefits.

We have shown that the spillover into the SSDI application pool is non-trivial. Our baseline estimate is that a decrease in the retirement-to-disability benefit ratio by 1 percentage point leads to a 0.28-percentage-point increase in the two-year SSDI application rate, or a 6.8-percent increase on a base of 3.1 percent. This effect appears to be driven by men, who have a 0.40-percentage-point increase in applications, while women seem nonresponsive. These estimates suggest that the characteristics of the SSDI application pool could change dramatically due to the increase in the FRA. Indeed, we do find significant differences in the applicants based on birth year. However, these changes in the applicant pool only lead to a decreased acceptance rate on the SSDI program once one applies. The SSDI recipient pool does not seem to change; we find no increase in SSDI benefit receipt based on birth year between age 55 and the FRA, once controlling for health and the determinants of SSDI insurance coverage. 


\section{References:}

Autor, David and Mark Duggan. 2006. “The Growth in the Social Security Disability Rolls: A Fiscal Crisis Unfolding.” Journal of Economic Perspectives, 20(3): 7196.

Bartus, Tamas. 2005. "Estimation of Marginal Effects using Margeff.” The Stata Journal, 5(3): 209-329.

Benitez-Silva, Hugo, Moshe Buchinsky, Hiu Man Chan, John Rust, and Sofia Sheidvasser. 1999. "An Empirical Analysis of the Social Security Disability Application, Appeal, and Award Process.” Labour Economics, (6): 147-178.

Cawley, John and Richard V. Burkhauser. 2006. "Beyond BMI: The Value of More Accurate Measures of Fatness and Obesity in Social Science Research.” Working Paper 12291. Cambridge, MA: National Bureau of Economic Research.

Duckworth, Angela and David Weir. 2010. "Personality, Lifetime Earnings, and Retirement Wealth.” Presentation at the $12^{\text {th }}$ Annual Retirement Research Consortium Conference, National Press Club, Washington DC, August 6.

Duggan, Mark, Perry Singleton, and Jae Song (2007). “Aching to Retire? The Rise in the Full Retirement Age and Its Impact on the Social Security Disability Rolls.” Journal of Public Economics, (91): 1327-1350.

Haider, Steven, and Gary Solon. 2000. "Nonrandom Selection in the HRS Social Security Earnings Sample.” Working Paper No. 00-01, RAND Labor and Population Program.

Judge, Timothy, Chad Higgins, Carl Thoresen, and Murray Barrick. 1999. “The Big Five Personality Traits, General Mental Ability, and Career Success Across the Life Span.” Personnel Psychology (52): 621-652.

Juhn, Chinhui and Simon Potter. 2006. "Changes in Labor Force Participation in the United States.” The Journal of Economic Perspectives, 20(3): 27-46.

Kapteyn, Arie, Pierre-Carl Michaud, James Smith, and Arthur Van Soest. 2006. "Survey Attrition and Non-Response in the Health and Retirement Study.” IZA Discussion Paper Series 2246.

Kopczuk, Wojciech and Jae Song. 2008. "Stylized Facts and Incentive Effects Related to Claiming of Retirement Benefits Based on Social Security Administration Data." Working Paper WP-2008-200. Ann Arbor, MI: University of Michigan Retirement Research Center. 
Li, Xiaoyan and Nicole Maestas. 2008. "Does the Rise in the Full Retirement Age Encourage Disability Benefit Applications? Evidence from the Health and Retirement Study.” Working Paper WP 2008-198. Ann Arbor, MI: University of Michigan Retirement Research Center.

Lindeboom, Maarten, Ana Llena-Nozal and Bas van der Klaauw. 2006. "Disability and Work: The Role of Health Shocks and Childhood Circumstances.” Discussion Paper 5685. London: Centre for Economic Policy Research.

Marmot, Michael, Martin Shipley, Eric Brunner, and Harry Hemingway. 2001. "Relative Contribution of Early Life and Adult Socioeconomic Factors to Adult Morbidity in Whitehall II Study.” Journal of Epidemiology and Community Health 55(5): 301-307.

Mitchell, Olivia S. and John W.R. Phillips. 2001. "Eligibility for Social Security Disability Insurance.” Working Paper WP 2001-011. Ann Arbor, MI: University of Michigan Retirement Research Center.

Norton, Edward, Hua Wang, and Chunrong Ai. 2004. "Computing Interaction Effects and Standard Errors in Logit and Probit Models.” The Stata Journal, 4(2): 154-167.

Olson, Janice A. 1999. "Linkages with Data from Social Security Administrative Records in the Health and Retirement Study.” Social Security Bulletin 62(2): 73-85.

Roberts, Brent, Nathan Kuncel, Rebecca Shiner, Avshalom Caspi and Lewis Goldberg. 2007. "The Power of Personality: The Comparative Validity of Personality Traits, Socioeconomic Status, and Cognitive Ability for Predicting Important Life Outcomes.” Perspectives on Psychological Science (2): 313-345.

Song, Jae and Joyce Manchester. 2007. "Have People Delayed Claiming Retirement Benefits? Responses to Changes in Social Security Rules.” Social Security Bulletin, 67(2). 
Table 1. Sample Selection Criteria

\begin{tabular}{|c|c|c|c|c|c|c|}
\hline & Individuals & $\begin{array}{l}\text { Person-Wave } \\
\text { Observations }\end{array}$ & Individuals & $\begin{array}{l}\text { Person-Wave } \\
\text { Observations }\end{array}$ & Individuals & $\begin{array}{l}\text { men } \\
\text { Person-Wave } \\
\text { Observations }\end{array}$ \\
\hline Number of people in RAND & 30,548 & -- & 13,255 & -- & 17,293 & -- \\
\hline Matched to SSA data & 20,786 & -- & 9,071 & -- & 11,715 & -- \\
\hline Birth Year Between 1935-1943 & 6,374 & 44,618 & 2,837 & 19,859 & 3,537 & 24,759 \\
\hline Age between 56 and 64 & 6,032 & 21,502 & 2,682 & 9,519 & 3,350 & 11,983 \\
\hline $\begin{array}{l}\text { Eligible for SSDI at time } t \\
\text { Not currently on or applying for SSDI at } \\
\text { time t }\end{array}$ & 4,455 & 14,552 & 2,274 & 7,532 & 2,181 & $\begin{array}{l}7,020 \\
6,585\end{array}$ \\
\hline Re-surveyed after time $\mathrm{t}$ & 4,130 & 13,215 & 2,104 & 6,827 & 2,026 & 6,388 \\
\hline Item non response & 4,028 & 13,037 & 2,042 & 6,716 & 1,986 & 6,321 \\
\hline Single & 2,838 & 9,050 & -- & -- & 796 & 2,334 \\
\hline
\end{tabular}


Table 2: SSDI Insurance Status at age 55

\begin{tabular}{|c|c|c|c|c|}
\hline & Single Men & Married Men & Single Women & Married Women \\
\hline \multirow[t]{2}{*}{ GED } & 0.127 & -0.138 & $0.377^{*}$ & $0.439 * * *$ \\
\hline & $(0.37)$ & $(0.87)$ & $(1.71)$ & (3.20) \\
\hline \multirow[t]{2}{*}{ High school graduate } & -0.037 & $0.172 *$ & $0.534 * * *$ & $0.491^{* * *}$ \\
\hline & $(0.21)$ & (1.67) & $(4.74)$ & (6.96) \\
\hline \multirow[t]{2}{*}{ Some college } & -0.238 & -0.125 & $0.672 * * *$ & $0.624 * * *$ \\
\hline & $(1.15)$ & $(1.18)$ & $(5.05)$ & $(7.57)$ \\
\hline \multirow[t]{2}{*}{ College or more } & 0.016 & -0.126 & $0.404 * * *$ & $0.406 * * *$ \\
\hline & $(0.08)$ & $(1.21)$ & (2.89) & $(4.54)$ \\
\hline \multirow[t]{2}{*}{ Ever divorced by age 55} & 0.067 & -0.102 & 0.134 & $0.147 * *$ \\
\hline & $(0.38)$ & (1.33) & $(1.28)$ & $(2.24)$ \\
\hline \multirow[t]{2}{*}{ Ever divorced unknown } & -0.001 & -0.440 & -0.245 & 0.278 \\
\hline & $(0.01)$ & $(1.49)$ & $(1.27)$ & $(0.80)$ \\
\hline \multirow[t]{2}{*}{ Ever widowed by age 55} & 0.162 & -0.141 & $-0.267 * *$ & 0.067 \\
\hline & $(0.60)$ & $(0.64)$ & $(2.44)$ & $(0.50)$ \\
\hline \multirow[t]{2}{*}{ Ever widowed unknown } & -0.152 & 0.170 & -0.128 & -0.059 \\
\hline & $(0.41)$ & $(0.33)$ & $(0.62)$ & $(0.15)$ \\
\hline \multirow[t]{2}{*}{ Age when last child born / adopted } & -0.002 & -0.003 & $-0.009 * *$ & $-0.008 * *$ \\
\hline & $(0.30)$ & $(0.68)$ & $(2.01)$ & $(2.13)$ \\
\hline \multirow[t]{2}{*}{ Unknown age when last child born / adopted } & $-0.827 * *$ & $-0.426 *$ & -0.032 & $-0.536 * *$ \\
\hline & $(2.17)$ & $(1.75)$ & $(0.08)$ & $(2.31)$ \\
\hline \multirow[t]{2}{*}{ Joins HRS before birth cohort } & 0.334 & -0.019 & $0.895 * * *$ & 0.107 \\
\hline & $(0.54)$ & $(0.08)$ & $(3.02)$ & $(0.72)$ \\
\hline \multirow[t]{2}{*}{ Born in 1938} & 0.162 & 0.126 & -0.162 & 0.121 \\
\hline & $(0.68)$ & $(1.13)$ & $(1.15)$ & $(1.37)$ \\
\hline \multirow[t]{2}{*}{ Born in 1939} & -0.026 & 0.174 & $0.290 *$ & 0.047 \\
\hline & $(0.13)$ & $(1.51)$ & $(1.93)$ & $(0.51)$ \\
\hline \multirow[t]{2}{*}{ Born in 1940} & 0.123 & 0.139 & 0.231 & $0.207 * *$ \\
\hline & $(0.56)$ & $(1.21)$ & $(1.56)$ & $(2.26)$ \\
\hline \multirow[t]{2}{*}{ Born in 1941} & -0.310 & $0.210 *$ & 0.083 & 0.023 \\
\hline & (1.53) & $(1.79)$ & $(0.62)$ & $(0.25)$ \\
\hline \multirow[t]{2}{*}{ Born in 1942} & -0.076 & 0.235 & 0.070 & $0.334^{* *}$ \\
\hline & $(0.26)$ & $(1.40)$ & $(0.31)$ & (2.13) \\
\hline \multirow[t]{2}{*}{ Born in 1943} & 0.497 & 0.008 & -0.074 & 0.028 \\
\hline & (1.23) & $(0.05)$ & $(0.34)$ & $(0.20)$ \\
\hline \multirow[t]{2}{*}{ Constant } & $0.937 * * *$ & $1.163 * * *$ & $0.368 * *$ & -0.049 \\
\hline & $(4.20)$ & $(7.05)$ & $(2.22)$ & $(0.39)$ \\
\hline Observations & 509 & 2,103 & 986 & 2,315 \\
\hline Percent insured at 55 & $81.1 \%$ & $86.3 \%$ & $71.0 \%$ & $59.9 \%$ \\
\hline
\end{tabular}

Absolute value of $\mathrm{z}$ statistics are in parentheses.

* significant at $10 \%$; ** significant at $5 \%$; *** significant at $1 \%$ 
Table 3: Descriptive Statistics

Whole Sample

Measures of SSDI Generosity and Benefits

Apply for SSDI between $t$ and $t+2$

SSR Benefit/SSDI Benefit at $\mathrm{t}+1$

PIA (Monthly SSDI Benefit Amount)

Lifetime Total Quarters of Coverage

Health and Disability Status

Sum of ADLs and Other Functional Limitations (0-13)

Self-Reported Fair or Poor Health

Sum of Major Health Conditions (0-8)

Often Troubled with Pain

Obese (Corrected BMI $>=30$ )

Subjective Probability of Living to 75+/Life Table Probability

Ever Applied for and Received SSDI before

Ever Applied for but Failed to Receive SSDI before

Covered by Health Insurance

Own Job

Spouses Job

Government Program

Demographics

Female

Age

Nonwhite

Not Married

Education

Less than high school

GED

High school graduate

Some college

College or more

Wealth and Income

Household Non-Labor Income

Net Worth

Job Characteristics

Blue-Collar

3-year Average of Labor Income

Lifetime Total Quarters of Coverage at $t$

$\mathrm{N}$ (person-waves)

Note: all measured at time t, unless noted otherwise.
Men Women

$\begin{array}{ccc}3.1 \% & 3.1 \% & 3.2 \% \\ 80.3 \% & 80.4 \% & 80.3 \% \\ \$ 1,311 & \$ 1,438 & \$ 874 \\ 138.9 & 147.1 & 115.3\end{array}$

$\begin{array}{ccc}1.51 & 1.29 & 2.15 \\ 16.0 \% & 15.0 \% & 18.6 \% \\ 1.24 & 1.16 & 1.48 \\ 22.0 \% & 20.9 \% & 25.1 \% \\ 38.4 \% & 36.9 \% & 42.8 \% \\ 96.3 \% & 98.7 \% & 89.4 \% \\ 1.4 \% & 1.4 \% & 1.7 \% \\ 3.1 \% & 2.7 \% & 4.2 \% \\ 80.6 \% & 82.7 \% & 74.6 \% \\ 67.6 \% & 67.9 \% & 66.6 \% \\ 11.3 \% & 14.1 \% & 3.4 \% \\ 6.9 \% & 7.1 \% & 6.3 \%\end{array}$

$25.8 \%$

$59.3 \quad 59.2 \quad 59.3$

$24.3 \% \quad 20.3 \% \quad 35.9 \%$

$38.1 \% \quad 16.6 \% \quad 100 \%$

$19.7 \% \quad 19.4 \% \quad 20.5 \%$

$\begin{array}{lll}4.8 \% & 5.0 \% & 4.5 \%\end{array}$

$31.1 \% \quad 30.8 \% \quad 32.0 \%$

$20.6 \% \quad 19.4 \% \quad 23.8 \%$

$23.8 \% \quad 25.4 \% \quad 19.2 \%$

$\begin{array}{ccc}\$ 8,980 & \$ 9,864 & \$ 8,128 \\ \$ 158,658 & \$ 197,231 & \$ 73,873\end{array}$

\begin{tabular}{ccc}
$39.8 \%$ & $42.9 \%$ & $30.8 \%$ \\
$\$ 37,104$ & $\$ 43,108$ & $\$ 25,756$ \\
138.9 & 147.1 & 115.3 \\
& & \\
9,050 & 6,716 & 2,334 \\
\hline
\end{tabular}


Table 4: Baseline Probit Estimates, by Gender

\begin{tabular}{|c|c|c|c|}
\hline 2-year SSDI Application Rate & Whole Sample & Men & Women \\
\hline \multicolumn{4}{|l|}{ Measures of SSDI Generosity and Benefits } \\
\hline SSR benefit/ SSDI benefit at $\mathrm{t}+1$ & $\begin{array}{l}-4.553 * * * \\
(4.10)\end{array}$ & $\begin{array}{l}-5.980 * * * \\
(4.31)\end{array}$ & $\begin{array}{l}-1.564 \\
(0.86)\end{array}$ \\
\hline DI benefit & $\begin{array}{l}-0.279 \\
(1.48)\end{array}$ & $\begin{array}{l}-0.329 \\
(1.55)\end{array}$ & $\begin{array}{l}-0.024 \\
(0.06)\end{array}$ \\
\hline \multicolumn{4}{|l|}{$\underline{\text { Health and Disability Status }}$} \\
\hline Number of ADLs & $\begin{array}{l}0.075^{* * *} \\
(4.99)\end{array}$ & $\begin{array}{l}0.079 * * * \\
(4.49)\end{array}$ & $\begin{array}{l}0.077^{* * *} \\
(2.62)\end{array}$ \\
\hline Self reported fair or poor health & $\begin{array}{l}0.171^{* *} \\
(2.10)\end{array}$ & $\begin{array}{c}0.134 \\
(1.38)\end{array}$ & $\begin{array}{l}0.293^{*} \\
(1.94)\end{array}$ \\
\hline Number of major conditions & $\begin{array}{l}0.093^{* * *} \\
(3.12)\end{array}$ & $\begin{array}{l}0.119 \text { *** } \\
(3.30)\end{array}$ & $\begin{array}{r}0.017 \\
(0.32)\end{array}$ \\
\hline Frequently in pain & $\begin{array}{c}0.038 \\
(0.54)\end{array}$ & $\begin{array}{c}0.042 \\
(0.50)\end{array}$ & $\begin{array}{c}0.034 \\
(0.24)\end{array}$ \\
\hline Obesity & $\begin{array}{l}-0.023 \\
(0.37)\end{array}$ & $\begin{array}{l}-0.078 \\
(1.05)\end{array}$ & $\begin{array}{c}0.103 \\
(0.89)\end{array}$ \\
\hline Subjective probability of living to 75 / Life table probability & $\begin{array}{l}-0.135^{*} \\
(1.85)\end{array}$ & $\begin{array}{l}-0.197^{* *} \\
(2.40)\end{array}$ & $\begin{array}{c}0.074 \\
(0.44)\end{array}$ \\
\hline Previously received SSDI & $\begin{array}{l}0.399^{* * *} \\
(2.58)\end{array}$ & $\begin{array}{l}0.439^{* *} \\
(2.21)\end{array}$ & $\begin{array}{c}0.306 \\
(1.18)\end{array}$ \\
\hline Previously rejected by SSDI & $\begin{array}{l}0.306^{* * * *} \\
(2.69)\end{array}$ & $\begin{array}{l}0.407 * * * \\
(3.09)\end{array}$ & $\begin{array}{c}0.082 \\
(0.37)\end{array}$ \\
\hline Have any health insurance & $\begin{array}{l}-0.074 \\
(1.06)\end{array}$ & $\begin{array}{l}-0.031 \\
(0.36)\end{array}$ & $\begin{array}{l}-0.143 \\
(1.20)\end{array}$ \\
\hline Demographics & & & \\
\hline Female & $\begin{array}{l}-0.245^{* *} \\
(2.37)\end{array}$ & & \\
\hline Not married & $\begin{array}{r}0.145 \\
(1.60)\end{array}$ & $\begin{array}{l}0.160^{*} \\
(1.66)\end{array}$ & \\
\hline Not white & $\begin{array}{c}0.021 \\
(0.29)\end{array}$ & $\begin{array}{c}0.049 \\
(0.54)\end{array}$ & $\begin{array}{c}0.049 \\
(0.40)\end{array}$ \\
\hline Age 57 & $\begin{array}{l}0.211^{* *} \\
(2.13)\end{array}$ & $\begin{array}{c}0.097 \\
(0.83)\end{array}$ & $\begin{array}{l}0.567 * * * \\
(2.92)\end{array}$ \\
\hline Age 58 & $\begin{array}{l}-0.059 \\
(0.50)\end{array}$ & $\begin{array}{l}-0.124 \\
(0.90)\end{array}$ & $\begin{array}{r}0.147 \\
(0.63)\end{array}$ \\
\hline Age 59 & $\begin{array}{l}0.192 * \\
(1.77)\end{array}$ & $\begin{array}{c}0.205 \\
(1.63)\end{array}$ & $\begin{array}{c}0.253 \\
(1.14)\end{array}$ \\
\hline Age 60 & $\begin{array}{l}0.271^{* *} \\
(2.33)\end{array}$ & $\begin{array}{l}0.321^{* *} \\
(2.37)\end{array}$ & $\begin{array}{c}0.176 \\
(0.74)\end{array}$ \\
\hline Age 61 or older & $\begin{array}{c}0.152 \\
(1.13)\end{array}$ & $\begin{array}{c}0.184 \\
(1.15)\end{array}$ & $\begin{array}{c}0.078 \\
(0.29)\end{array}$ \\
\hline Wealth & & & \\
\hline Average income over last three years & $\begin{array}{l}-0.023 \\
(1.00)\end{array}$ & $\begin{array}{l}-0.011 \\
(0.44)\end{array}$ & $\begin{array}{l}-0.085 \\
(1.60)\end{array}$ \\
\hline Household non labor income & $\begin{array}{l}-0.007 \\
(0.51)\end{array}$ & $\begin{array}{l}-0.012 \\
(0.64)\end{array}$ & $\begin{array}{c}0.004 \\
(0.14)\end{array}$ \\
\hline Net worth & $\begin{array}{l}-0.001 \\
(0.33)\end{array}$ & $\begin{array}{l}-0.001 \\
(0.30)\end{array}$ & $\begin{array}{c}0.001 \\
(0.35)\end{array}$ \\
\hline Total SSA covered quarters & $\begin{array}{l}0.377^{* *} \\
(2.02)\end{array}$ & $\begin{array}{l}0.409 * \\
(1.79)\end{array}$ & $\begin{array}{c}0.242 \\
(0.71)\end{array}$ \\
\hline Observations & 9,050 & 6,716 & 2,334 \\
\hline
\end{tabular}

Probit coefficients and Robust $\mathrm{z}$ statistics (in parentheses) are presented.

* significant at $10 \%$; ** significant at $5 \%$; *** significant at $1 \%$

Note: Regression also includes year indicator variables and an indicator variable for non-response to self-reported probability of living until age 75. 
Table 4(continued): Baseline Probit Estimates, by Gender

\begin{tabular}{|c|c|c|c|}
\hline 2-year SSDI Application Rate & Whole Sample & Men & Women \\
\hline \multicolumn{4}{|l|}{ Education } \\
\hline GED & $\begin{array}{l}-0.048 \\
(0.35)\end{array}$ & $\begin{array}{l}-0.121 \\
(0.79)\end{array}$ & $\begin{array}{c}0.249 \\
(0.97)\end{array}$ \\
\hline High school graduate & $\begin{array}{l}-0.024 \\
(0.29)\end{array}$ & $\begin{array}{l}-0.102 \\
(1.06)\end{array}$ & $\begin{array}{c}0.198 \\
(1.21)\end{array}$ \\
\hline Some college & $\begin{array}{c}0.019 \\
(0.20)\end{array}$ & $\begin{array}{l}-0.045 \\
(0.41)\end{array}$ & $\begin{array}{c}0.120 \\
(0.63)\end{array}$ \\
\hline College or more & $\begin{array}{l}-0.206^{*} \\
(1.84)\end{array}$ & $\begin{array}{l}-0.206 \\
(1.63)\end{array}$ & $\begin{array}{l}-0.286 \\
(1.10)\end{array}$ \\
\hline \multicolumn{4}{|l|}{ Determinants of Insurance Status } \\
\hline Have you ever been divorced & $\begin{array}{c}0.059 \\
(0.90)\end{array}$ & $\begin{array}{l}-0.018 \\
(0.23)\end{array}$ & $\begin{array}{l}0.368^{* * *} \\
(2.61)\end{array}$ \\
\hline Have you ever been widowed & $\begin{array}{l}-0.116 \\
(1.03)\end{array}$ & $\begin{array}{l}-0.021 \\
(0.11)\end{array}$ & $\begin{array}{l}-0.036 \\
(0.28)\end{array}$ \\
\hline Age when last child born or adopted & $\begin{array}{c}0.005 \\
(1.55)\end{array}$ & $\begin{array}{c}0.006 \\
(1.34)\end{array}$ & $\begin{array}{c}0.004 \\
(0.63)\end{array}$ \\
\hline Missing age when last child born or adopted & $\begin{array}{l}-0.069 \\
(0.28)\end{array}$ & $\begin{array}{l}-0.035 \\
(0.12)\end{array}$ & $\begin{array}{l}-0.420 \\
(0.83)\end{array}$ \\
\hline Interviewed before 1998 & $\begin{array}{l}-0.099 \\
(0.56)\end{array}$ & $\begin{array}{c}0.070 \\
(0.31)\end{array}$ & $\begin{array}{l}-0.284 \\
(1.18)\end{array}$ \\
\hline Constant & $\begin{array}{l}1.276 \\
(1.42)\end{array}$ & $\begin{array}{l}2.511^{* *} \\
(2.19)\end{array}$ & $\begin{array}{l}-1.862 \\
(1.29)\end{array}$ \\
\hline Observations & 9,050 & 6,716 & 2,334 \\
\hline
\end{tabular}

Probit coefficients and Robust $\mathrm{z}$ statistics (in parentheses) are presented.

* significant at $10 \%$; $* *$ significant at $5 \%$; *** significant at $1 \%$

Note: Regression also includes year indicator variables and an indicator variable for non-response to self-reported probability of living until age 75. 
Table 5: Quantifying the Application Effect

\begin{tabular}{|c|c|c|c|c|c|c|c|}
\hline Birth Year & $\begin{array}{l}\text { Percentage Point } \\
\text { Change in SS/DI } \\
\text { benefits }\end{array}$ & $\begin{array}{l}\text { Average 2-year } \\
\text { Marginal Effect } \\
\text { for Men }\end{array}$ & $\begin{array}{c}\text { Percentage } \\
\text { Point increase } \\
\text { in Applications } \\
\end{array}$ & $\begin{array}{c}\text { Number of } \\
\text { Men at age } 55\end{array}$ & $\begin{array}{l}\text { Percent Insured } \\
\text { for SSDI }\end{array}$ & $\begin{array}{l}\text { Number of increased } \\
\text { SSDI applications }\end{array}$ & $\begin{array}{c}\text { Number of increased } \\
\text { SSDI applications } \\
\text { between ages 55-65 }\end{array}$ \\
\hline 1938 & -0.8 & -0.40 & 0.32 & $1,109,836$ & $85 \%$ & 2,993 & 14,966 \\
\hline 1939 & -1.7 & -0.40 & 0.67 & $1,081,317$ & $85 \%$ & 6,197 & 30,986 \\
\hline 1940 & -2.5 & -0.40 & 0.99 & $1,145,024$ & $85 \%$ & 9,651 & 48,253 \\
\hline 1941 & -3.3 & -0.40 & 1.31 & $1,301,225$ & $85 \%$ & 14,477 & 72,383 \\
\hline 1942 & -4.2 & -0.40 & 1.67 & $1,261,658$ & $85 \%$ & 17,864 & 89,322 \\
\hline 1943 & -5.0 & -0.40 & 1.98 & $1,460,293$ & $85 \%$ & 24,615 & 123,077 \\
\hline
\end{tabular}

Total Increase

333,035

Source: Authors' calculations from the Health and Retirement Study and the Current Population Survey (various years). 


\begin{tabular}{|c|c|c|c|}
\hline & Whole Sample & Men & Women \\
\hline \multicolumn{4}{|l|}{ Birth Year } \\
\hline Born in 1936 & $\begin{array}{l}-0.250 \\
(1.44)\end{array}$ & $\begin{array}{l}-0.096 \\
(0.50)\end{array}$ & $\begin{array}{l}-1.151^{* *} \\
(2.17)\end{array}$ \\
\hline Born in 1937 & $\begin{array}{l}-0.214 \\
(1.28)\end{array}$ & $\begin{array}{l}-0.266 \\
(1.32)\end{array}$ & $\begin{array}{l}-0.148 \\
(0.47)\end{array}$ \\
\hline Born in 1938 & $\begin{array}{l}-0.152 \\
(0.96)\end{array}$ & $\begin{array}{l}-0.285 \\
(1.49)\end{array}$ & $\begin{array}{c}0.154 \\
(0.51)\end{array}$ \\
\hline Born in 1939 & $\begin{array}{l}-0.163 \\
(1.00)\end{array}$ & $\begin{array}{l}-0.124 \\
(0.68)\end{array}$ & $\begin{array}{l}-0.239 \\
(0.65)\end{array}$ \\
\hline Born in 1940 & $\begin{array}{l}-0.139 \\
(0.86)\end{array}$ & $\begin{array}{l}-0.152 \\
(0.81)\end{array}$ & $\begin{array}{l}-0.143 \\
(0.46)\end{array}$ \\
\hline Born in 1941 & $\begin{array}{l}-0.035 \\
(0.19)\end{array}$ & $\begin{array}{l}-0.165 \\
(0.75)\end{array}$ & $\begin{array}{c}0.199 \\
(0.60)\end{array}$ \\
\hline \multicolumn{4}{|c|}{ Measures of SSDI Generosity and Benefits } \\
\hline DI benefit & $\begin{array}{l}0.354^{*} \\
(1.67)\end{array}$ & $\begin{array}{c}0.352 \\
(1.43)\end{array}$ & $\begin{array}{c}0.452 \\
(1.02)\end{array}$ \\
\hline \multicolumn{4}{|l|}{$\underline{\text { Health and Disability Status at age } 66}$} \\
\hline Number of ADLs & $\begin{array}{l}0.150^{* * *} \\
(7.84)\end{array}$ & $\begin{array}{l}0.144^{* * *} \\
(6.32)\end{array}$ & $\begin{array}{l}0.182^{* * *} \\
(4.96)\end{array}$ \\
\hline Self reported fair or poor health & $\begin{array}{l}0.236 * * \\
(2.05)\end{array}$ & $\begin{array}{c}0.231^{*} \\
(1.68)\end{array}$ & $\begin{array}{r}0.157 \\
(0.74)\end{array}$ \\
\hline Number of major conditions & $\begin{array}{l}0.132^{* * *} \\
(3.63)\end{array}$ & $\begin{array}{l}0.159^{* * *} \\
(3.77)\end{array}$ & $\begin{array}{c}0.098 \\
(1.35)\end{array}$ \\
\hline Frequently in pain & $\begin{array}{l}0.174^{*} \\
(1.78)\end{array}$ & $\begin{array}{c}0.108 \\
(0.91)\end{array}$ & $\begin{array}{r}0.304 \\
(1.58)\end{array}$ \\
\hline Obesity & $\begin{array}{l}-0.240^{* *} \\
(2.55)\end{array}$ & $\begin{array}{l}-0.367^{* * *} \\
(3.16)\end{array}$ & $\begin{array}{l}-0.015 \\
(0.09)\end{array}$ \\
\hline \multicolumn{4}{|l|}{ Demographics } \\
\hline Female & $\begin{array}{l}-0.328^{* *} \\
(2.14)\end{array}$ & & \\
\hline Not white & $\begin{array}{c}0.128 \\
(1.13)\end{array}$ & $\begin{array}{r}0.100 \\
(0.68)\end{array}$ & $\begin{array}{c}0.248 \\
(1.31)\end{array}$ \\
\hline Married at age 66 & $\begin{array}{l}-0.195 \\
(1.35)\end{array}$ & $\begin{array}{l}-0.094 \\
(0.65)\end{array}$ & \\
\hline \multicolumn{4}{|l|}{ Wealth at age 66} \\
\hline Household non labor income & $\begin{array}{l}-0.003 \\
(0.18)\end{array}$ & $\begin{array}{l}-0.115^{*} \\
(1.68)\end{array}$ & $\begin{array}{c}0.030 \\
(0.95)\end{array}$ \\
\hline Net worth & $\begin{array}{c}0.001 \\
(0.34)\end{array}$ & $\begin{array}{c}0.001 \\
(0.58)\end{array}$ & $\begin{array}{l}-0.015 \\
(0.44)\end{array}$ \\
\hline Total SSA covered quarters & $\begin{array}{l}-0.731^{* * * *} \\
(3.68)\end{array}$ & $\begin{array}{l}-0.650^{* * * *} \\
(2.76)\end{array}$ & $\begin{array}{l}-0.979 * * \\
(2.37)\end{array}$ \\
\hline \multicolumn{4}{|l|}{ Education } \\
\hline GED & $\begin{array}{c}0.067 \\
(0.32)\end{array}$ & $\begin{array}{l}-0.063 \\
(0.26)\end{array}$ & $\begin{array}{c}0.215 \\
(0.53)\end{array}$ \\
\hline High school graduate & $\begin{array}{c}0.179 \\
(1.36)\end{array}$ & $\begin{array}{c}0.123 \\
(0.80)\end{array}$ & $\begin{array}{c}0.281 \\
(1.05)\end{array}$ \\
\hline Some college & $\begin{array}{l}-0.156 \\
(0.98)\end{array}$ & $\begin{array}{l}-0.237 \\
(1.24)\end{array}$ & $\begin{array}{l}-0.037 \\
(0.11)\end{array}$ \\
\hline College or more & $\begin{array}{l}-0.488^{* * * *} \\
(2.68)\end{array}$ & $\begin{array}{l}-0.543^{* *} \\
(2.55)\end{array}$ & $\begin{array}{l}-0.407 \\
(1.20)\end{array}$ \\
\hline Constant & $\begin{array}{l}-0.975 * * * \\
(2.97)\end{array}$ & $\begin{array}{l}-0.920 * * \\
(2.48)\end{array}$ & $\begin{array}{l}-1.571^{* * *} \\
(2.62)\end{array}$ \\
\hline Observations & 2,108 & 1,514 & 594 \\
\hline
\end{tabular}

Coefficients and Robust z statistics (in parentheses) of probit regression are presented. Sample: Those insured for SSDI and not receiving at age 55, and observed again at age 66 . * significant at $10 \%$; ** significant at $5 \%$; *** significant at $1 \%$

Note: Regression also includes whether the respondent has been divorced/widowed, age they had their last child, a variable if that age is unknown. 
Table 7: Characteristics of SSDI Applicants, by Birth Cohort and Gender

\begin{tabular}{|c|c|c|c|c|c|c|}
\hline & & Men & & Wo & men & \\
\hline & Born $<1938$ & Born $\geq 1938$ & & Born $<1938$ & Born $\geq 1938$ & \\
\hline Measures of SSDI Generosity and Benefits & & & & & & \\
\hline SSR Benefit/SSDI Benefit at $\mathrm{t}+1$ & $80.8 \%$ & $77.7 \%$ & *** & $81.8 \%$ & $78.3 \%$ & $* * *$ \\
\hline PIA (Monthly SSDI Benefit Amount) & $\$ 1,216$ & $\$ 1,310$ & ** & $\$ 713$ & $\$ 901$ & ** \\
\hline Health and Disability Status & & & & & & \\
\hline Sum of ADLs and Other Functional Limitations (0-13) & 3.28 & 2.91 & & 3.18 & 4.21 & \\
\hline Self-Reported Fair or Poor Health & $41.4 \%$ & $36.4 \%$ & & $54.5 \%$ & $38.5 \%$ & \\
\hline Sum of Major Health Conditions (0-8) & 1.55 & 1.94 & $* *$ & 1.64 & 2.06 & \\
\hline HBP & $32.2 \%$ & $50.0 \%$ & $* * *$ & $36.4 \%$ & $46.2 \%$ & \\
\hline Cancer & $3.4 \%$ & $10.2 \%$ & $*$ & $4.5 \%$ & $13.5 \%$ & \\
\hline Diabetes & $13.8 \%$ & $25.4 \%$ & $* *$ & $18.2 \%$ & $25.0 \%$ & \\
\hline Often Troubled with Pain & $42.5 \%$ & $38.1 \%$ & & $36.4 \%$ & $48.1 \%$ & \\
\hline Obese (Corrected BMI>=30) & $35.6 \%$ & $44.9 \%$ & & $50.0 \%$ & $59.6 \%$ & \\
\hline Subjective Probability of Living to $75+/$ Life Table & & & & & & \\
\hline Probability & $86.8 \%$ & $79.1 \%$ & & $73.9 \%$ & $89.6 \%$ & \\
\hline Ever Applied for and Received SSDI before & $8.0 \%$ & $6.8 \%$ & & $13.6 \%$ & $3.8 \%$ & \\
\hline Ever Applied for but Failed to Receive SSDI before & $16.1 \%$ & $11.9 \%$ & & $13.6 \%$ & $13.5 \%$ & \\
\hline Demographics, SES and Personality & & & & & & \\
\hline Age & 58.9 & 58.8 & & 58.9 & 58.7 & \\
\hline Education & & & & & & \\
\hline Less than high school & $33.3 \%$ & $26.3 \%$ & & $22.7 \%$ & $23.1 \%$ & \\
\hline GED & $5.8 \%$ & $5.9 \%$ & & $9.1 \%$ & $5.8 \%$ & \\
\hline High school graduate & $33.3 \%$ & $29.7 \%$ & & $50.0 \%$ & $34.6 \%$ & \\
\hline Some college & $20.7 \%$ & $22.0 \%$ & & $13.6 \%$ & $30.8 \%$ & $*$ \\
\hline College or more & $6.9 \%$ & $16.1 \%$ & $* *$ & $4.6 \%$ & $5.8 \%$ & \\
\hline Nonwhite & $23.0 \%$ & $28.0 \%$ & & $45.5 \%$ & $40.4 \%$ & \\
\hline Not Married & $31.0 \%$ & $22.0 \%$ & & -- & -- & \\
\hline Household Non-Labor Income & $\$ 6,802$ & $\$ 2,385$ & & $\$ 0$ & $\$ 3,668$ & \\
\hline Net Worth & $\$ 93,926$ & $\$ 115,047$ & & $\$ 31,149$ & $\$ 31,011$ & \\
\hline Covered by Health Insurance & $74.7 \%$ & $78.0 \%$ & & $59.1 \%$ & $69.2 \%$ & \\
\hline Own Job & $56.3 \%$ & $67.8 \%$ & * & $54.5 \%$ & $65.4 \%$ & \\
\hline Spouses Job & $13.8 \%$ & $12.7 \%$ & & $0.0 \%$ & $1.9 \%$ & \\
\hline Government Program & $11.5 \%$ & $2.5 \%$ & $* *$ & $4.5 \%$ & $1.9 \%$ & \\
\hline Job Characteristics & & & & & & \\
\hline Blue-Collar & $45.0 \%$ & $46.2 \%$ & & $36.8 \%$ & $27.3 \%$ & \\
\hline Labor Income & $\$ 39,314$ & $\$ 33,619$ & & $\$ 23,845$ & $\$ 18,169$ & \\
\hline Lifetime Total Quarters of Coverage at t & 141.5 & 147.2 & * & 111.4 & 115.3 & \\
\hline $\mathrm{N}$ (person-waves) & 87 & 118 & & 22 & 52 & \\
\hline
\end{tabular}

Note: All covariates are measured at time of application. 
Figure 1: Ratio of Retirement Benefits to Disability Benefits, by Age and Birth Year

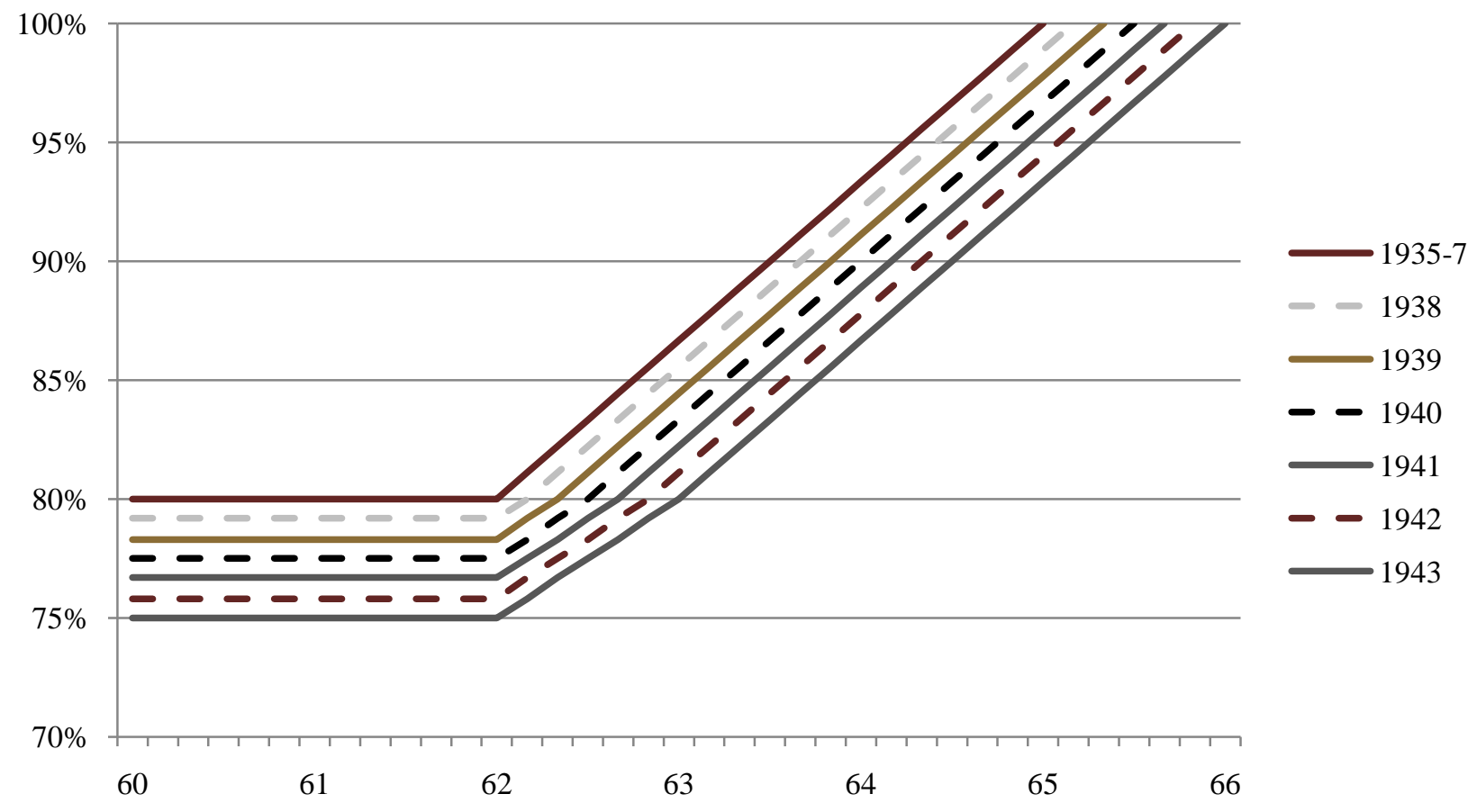




\section{RECENT WORKING PAPERS FROM THE}

\section{CENTER FOR RETIREMENT RESEARCH AT BOSTON COLLEGE}

Is the Reduction in Older Workers' Job Tenure a Cause for Concern?

Steven A. Sass and Anthony Webb, December 2010

Accounting for Disability Insurance in the Dynamic Relationship Between Disability Onset and Earnings

Perry Singleton, November 2010

The Treatment of Married Women by the Social Security Retirement Program

Andrew G. Biggs, Gayle L. Reznik, and Nada O. Eissa, November 2010

What is the Impact of Foreclosures on Retirement Security?

Irena Dushi, Leora Friedberg, and Anthony Webb, November 2010

Children and Household Utility: Evidence from Kids Flying the Coop

Norma B. Coe and Anthony Webb, November 2010

Overview of the CRR 2009 Retirement Survey

Alicia H. Munnell, Norma B. Coe, Kelly Haverstick, and Steven A. Sass, October 2010

State Wage-Payment Laws, the Pension Protection Act of 2006, and 401(k) Saving Behavior

Gary V. Englehardt, October 2010

Asset Cycles and the Retirement Decisions of Older Workers

Jan Ondrich, October 2010

Price Deflators, the Trust Fund Forecast, and Social Security Solvency

Barry Bosworth, October 2010

The Impact of a DROP Program on the Age of Retirement and Employer Pension Costs Samson Alva, Norma B. Coe, and Anthony Webb, September 2010

Housing Consumption in Late Life: The Role of Income, Health Shocks, and Marital Shocks

Douglas A. Wolf and Janet M. Wilmoth, September 2010

Adjusting Social Security for Increasing Life Expectancy: Effects on Progressivity Courtney Monk, John A. Turner, and Natalia A. Zhivan, August 2010

Work and Retirement Patterns for the G.I. Generation, Silent Generation, and Early Boomers: Thirty Years of Change

Richard W. Johnson, Barbara A. Butrica, and Corina Mommaerts, July 2010

All working papers are available on the Center for Retirement Research website (http://crr.bc.edu) and can be requested by e-mail (crr@bc.edu) or phone (617-552-1762). 